\title{
The Abundance of Pioneer Vegetation and Their Interaction with Endomycorrhiza at Different Land Qualities after Merapi Eruption
}

\author{
Cahyono Agus ${ }^{1^{*}}$, Dewi Wulandari ${ }^{2}$ \\ ${ }^{1}$ Faculty of Forestry, Gadjah Mada University, Bulaksumur, Yogyakarta, 55281, Indonesia \\ ${ }^{2}$ United Graduated School of Agriculture, Iwate University, Japan
}

Received March 5, 2012/Accepted June 4, 2012

\begin{abstract}
Eruption of Merapi volcano caused accumulation of lahar materials that led to extensive land degradation. This research was to study the population of pioneer plants and their correlation with endomycorrhiza population at different land qualities after Merapi eruption. Samples of soil, pioneer plants, and endomycorrhiza were collected from Merapi volcano, 1 year after eruption, using stratified sampling method based on plant densities, with the following categories: dense vegetation, moderately dense vegetation, sparse vegetation, and control (bare land), with 3 replications for each category. Pioneer plants and endomycorrhiza were identified. Plant biomass, soil pH, total-C,-N, and exchangeable- $K,-C a,-M g,-F e$ were analyzed. The abundance of pioneer plants and their interaction with mycorrhiza was strongly correlated with depth of eruption material, quantity of sandy texture, soil $\mathrm{pH}$, total-C and total- $\mathrm{N}$, exchangeable-K, exchangeable-Ca, exchangeable-Mg, and exchangeable-Fe. Among the 12 identified pioneer plants, only Acacia villosa, Fiurena ciliaris, and Bidens pilosa were recommended as plantremediator to improve soil chemical, physical and biological properties. Among the 3 genera of endomycorrhiza (Acaulospora, Gigaspora, Glomus), only Acaulospora was recommended to be a biological agent to rehabilitate sandy soil area. This research indicated that adaptive pioneer plants and endomycorrhiza were likely to be suitable for biological agents to stimulate recovery of degraded land through improvement of physical, chemical, and biological properties, that will stimulate plant growth and biodiversity.
\end{abstract}

Keywords: eruption of Merapi, endomycorrhiza, land quality, pioneer plant

*Correspondence author, email: acahyono@ugm.ac.id,telp.+62-8156888041

\section{Introduction}

Mount Merapi volcano is one of the most active volcano in the world and has been recorded for its explosive eruption for the last 10,000 years (Newhall et al. 2000). One of the greatest eruption of Merapi occurred in $19^{\text {th }}$ century of 1872, where the explosion reached distance of up to $20 \mathrm{~km}$ (Wilson et al. 2007). Accumulation of lahar materials destroyed the soil physical, chemical, and biological properties, resulted on inappropriate condition for plant growth. Such destruction caused environmental damage, such as increasing of soil acidity, nutrient deficiency, and low soil organic matter content which constituted the limiting factors for the soil, and finally affected on ecosystem stability (Wilson et al. 2007). Merapi eruption exhibited barrenness and drought due to lost vegetation in affected land. On the other hand, efforts to improve such condition were still limited due to constraints in the lack of technology and funding.

Pioneer vegetation possessed important role for supplying litter and organic matter in the soil (Lei \& Duan 2008) that may create an appropriate condition for succession and emergence of other plants. Pioneer plants possessed potency for improving degraded land, dry land (Zhang et al. 2004), and polluted land (Lei \& Duan 2008). The appearance of pioneer vegetation contributes to the final succession of vegetation due to their ability to change microclimatic conditions such as light, water, and nutrient availability which determine the final succession of plant seedlings (Connel \& Slatyer 1977). Selection and disposition of pioneer plants were also reported the quality improvement in the landscape and ecological condition of the degraded land (Zhang et al. 2004).

Mycorrhiza fungi which constitute the microbial symbiosis in the soil, had high survival ability in various environmental conditions (Marschner 1995). Mycorrhiza fungi develop not only in soil with good drainage, but also in water-inundated land, such as those in wet land rice field (Solaiman \& Hirata 1997a; 1997b). This fungi is even has ability to survive in very poor and polluted environment (Aggangan et al. 1998). Considering on this function, appropriate mycorrhizal fungi with pioneer vegetation as the host plant can be one of possible method to remediate such degraded area such as in post erupted area of Mount Merapi.

Selection of adaptive pioneer plants with ability in high production of organic matter and biomass in degraded land can be assisted with mycorrhizal mutualistic simbiosis (Maki et al. 2008). This technique is expected to serve as an alternative solution and cheap method to overcome such 
problem, in consideration that addition of top soil and soil amendment chemicals requires very high cost.

The research on analysis of pioneer vegetation, mycorrhiza and land quality, after 1 year Merapi volcano eruption aimed to study the close relationship between the abundance of pioneer vegetation and mycorrhiza at various different land qualities after Merapi eruption disaster. These research results were expected to serve a basic data for technology development on rehabilitation of degraded land after Merapi volcano eruption.

\section{Methods}

This research was conducted on May-November 2007. Field study was conducted along the river of Kaliadem in the south slope of Merapi volcano which was overlain by Merapi eruption in year 2006. Analysis on soil, plants, and plant tissues were conducted in Laboratory of Physiology and Forest Soil, Faculty of Forestry, University of Gadjah Mada Yogyakarta.

Sample plots were selected and constructed by using stratified soil sampling method. Sample plots had square shape of $2 \times 2 \mathrm{~m}$, comprising 3 replications for each stratum. Analysis was conducted by comparing those sample plots, based on biomass differences of the pioneer vegetation, mycorrhiza abundance, and soil physical and chemical properties, after being overlain for 1 year by Merapi eruption deposit. Observation was conducted in 4 plots on the basis of densities of pioneer plants, which could be described as follows:

1 D: dense vegetation; land with dense vegetation, or more than 50 plants in each observation plot.

2 M: moderately dense vegetation; land with moderate level of vegetation density or with $20-50$ plants in each observation plot.

3 S: sparse vegetation; land with low level of vegetation density (sparse), or with less than 20 plants in each observation plot.

$4 \mathrm{C}$ : control/without vegetation; land without vegetation (bare land).

Collection of soil samples was conducted randomly at 2 layers of soil with $0-2 \mathrm{~cm}$ depth and $2-15 \mathrm{~cm}$ depth on rhizosphere of pioneer plants. Each soil sample had 3 replications. Soil physical properties were analized by measuring the depth of soil erosion deposit, soil moisture content (gravimetric method), and soil texture (gravimetric method). Soil chemical properties were analyzed for soil $\mathrm{pH}$, soil organic matter content/soil total C (Walkley \& Black method), soil total-N (Kjeldahl method), exchangeable-Ca, exchangeable-Mg, exchangeable-K, and exchangeable-Fe as described in Prawirowardoyo (1987).

Collection of specimen for each pioneer species was conducted in each observation plot. Identification of pioneer plants was conducted by using manual book for plant identification (Soerjani et al. 1987). Sample of pioneer plants was collected wholly, ranging from roots to leaves. Biomass measurement was conducted gravimetrically by measuring total biomass of pioneer plants. Chemical analysis on plant tissue was conducted by measuring content of total$\mathrm{C}$, total-N, and $\mathrm{C}-\mathrm{N}$ ratio (Prawirowardoyo 1987). Endomycorrhiza was isolated by using wet sieving method (Brundrett et al. 1996). Isolated endomycorrhiza were then measured for its population. Endomycorrhiza were identified based on its morphology to the genera level. Endomycorrhiza infection was observed by harvesting root of pioneer plants. Roots were cleared in $\mathrm{KOH}\left(100 \mathrm{~g} \ell^{-1}\right)$ at $80{ }^{\circ} \mathrm{C}$ for 5 minutes, acidified with diluted $\mathrm{HCl}$, and stained with $500 \mathrm{mg} \ell^{-1}$ tryphan blue. Mycorrhizal colonization was examined using gridline intersect method (Schenck 1982). Statistical data analysis was conducted by analysis the effect of pioneer vegetation density on the tested parameters.

\section{Results and Discussion}

Identification of pioneer plants at 1 year after Merapi volcano eruption showed that there were 12 species of pioneer plants in land of former deposit of lahar, namely: Acacia villos (V1), Fiurena ciliaris (V2), Bidens pilosa (V3), Adenantera vavonica (V4), Sonchus arvensis (V5), Ageratum conyzoide (V6), Parkia speciosa (V7), Elephantopus scaber L. (V8), Erigeron sumatrensis (V9), Amaranthus gracilis (V10), Eupatorium triplinerve (V11), and Rauwolfra serpentina (V12) (Table 1). There was 1 woody plant (V1), and others were eleven pioneer plant species of bush vegetation (V2-12). This result was consistent with data from Corlett (1991) who reported that the initial stage of succession was dominated by several woody pioneer plants.

Table 1 Identification of pioneer plants, 1 year after eruption of Merapi volcano

\begin{tabular}{lll}
\hline Notation & Scientific name & Local name \\
\hline V1 & Acacia villosa & Lamtoro merah \\
V2 & Fiurena ciliaris & Ketut/ajeran \\
V3 & Bidens pilosa & Rumput gajah \\
V4 & Adenantera vavonica & Sogok telik, Legum \\
V5 & Sonchus arvensis & Tempuyung \\
V6 & Ageratum conyzoides & Babadatan \\
V7 & Parkia speciosa & Petai \\
V8 & Elephantopus scaber & Tapak liman \\
V9 & Erigeron sumatrensis & Sembungan \\
V10 & Amaranthus gracilis & Bayam putih \\
V11 & Eupatorium triplinerve & Godong prasman/Raja panah \\
V12 & Rauwolfra serpentina & Chandra \\
\hline
\end{tabular}


Table 2 Soil physical and chemical properties in each plot of vegetation density, 1 year after Merapi volcano eruption

\begin{tabular}{lcccc}
\hline \multicolumn{1}{c}{ Plot } & Depth of deposit & Soil texture & $\mathrm{pH}-\mathrm{H}_{2} \mathrm{O}$ & Organic matter $(\%)$ \\
\hline Dense & $3 \mathrm{~cm}$ & Loamy sand & 5.40 & 1.83 \\
Moderate & $5 \mathrm{~cm}$ & Loamy sand & 5.32 & 1.83 \\
Sparse & $>1 \mathrm{~m}$ & Loamy sand & 5.11 & 0.67 \\
Control (bare land) & $>2 \mathrm{~m}$ & sand & 5.10 & 0.14 \\
\hline
\end{tabular}

There were 3 species of pioneer plants in dense vegetation plot, namely V1, V2, and V3. Five species of vegetation, namely V1, V2, V3, V4, and V5 were found in moderately dense vegetation plot. Others 8 species of plants, namely V1, V2, V7, V8, V9, V10, V11, and V12 were found in sparse vegetation plot. Number of vegetation species was found greater in sparse vegetation land than those in dense vegetation plot. Biodiversity of plant species decreased with increasing density of vegetation in the observed land. This phenomenon was also explained by Henry et al. (1999) in his study which showed that plant species diversity was significantly affected by plant density and this was related with competitive ability of each plant species.

Plant species Acacia villosa appeared to be dominant in each observation plot, whereas plant species Fiurena ciliaris appeared to be dominant in land with moderate density. As woody species, Acacia vilosa produced a large amount of biomass in each plot observation. Pioneer plant, such as shrub or bush would be replaced by woody plants in the initial stage of succession. Another possible reason is because of a high adaptability of the pioneer plants due to ability to have symbioses with symbiotic microorganism, such as endomycorrhiza (Garg \& Chandel 2010). This phenomenon was proved by occurrence of mycorrhizal population and the large number of root nodules in this plant, which showed the presence of association with nitrogen fixing bacteria. In considering with this plant ability to have such symbiosis with soil microorganism, this vegetation can be recommended as potential pioneer plants to be grown for remediation purpose in degraded land which is contain of low nutrients and sand texture.

Table 2 showed soil chemical and physical characteristics in each plot of plant density observation. The amount of plant biomass was affected by depth of Merapi lahar deposit, which had negative correlation. The survival ability of pioneer plant decreased by the increased of the depth of lahar deposit with the consequence that the plant density became lower, although the biodiversity became greater. This result was consistent with the previous research by Sklenar et al. (2010) reported the level of biodiversity of pioneer plants in young lahar. Land with deposit depth of more than 2 meters with sand texture had impact in the inability of pioneer plants to grow. At more than $1 \mathrm{~m}$ lahar deposit depth with loamy sand texture showed that pioneer plants were able to start to grow, although still to be sparse. Relatively dense pioneer vegetation was appeared when the lahar deposit depth was only about $5 \mathrm{~cm}$ with loamy sand texture. In deeper accumulation of lahar deposit, topsoil is covered and resulted on the change of soil texture into sand, including change on availability of soil nutrient for plant. Nutrients in soil constituted the limiting factor for plant growth in sandy land(Li et al. 2011).

Erosion has high contribution on the loss of soil fertility (Vaje et al. 2005) and decreases quality of soil physical, chemical, and biological properties after volcanic eruption (Austin 1984). Accumulation of lahar materials and loss of soil media were drifted away by erosion. However, eutrophication process through accumulation of volcanic ash and soil media which were transported, would be able to provide better soil physical and chemical properties, so that these would be able to stimulate growth of pioneer plants.

Values of $\mathrm{pH}-\mathrm{H}_{2} \mathrm{O}$ tended to increase along with the increase of density of the emerging pioneer plants, and categorized as acid soil. This low soil $\mathrm{pH}$ may be due to mineralogical composition of the parent material and the initial process of pedogenesis (Norambuena et al. 2011). Soil organic matter content increased sharply with the presence of pioneer vegetation, from only $0.14 \%$ in bare land without vegetation and increased up to $1.83 \%$ in moderately dense and dense vegetation plots. This data was consistent with results from Norambuena et al. (2011) that reported low content of soil organic matter in plot with low abundance of vegetation in the volcano area. Around $10-20 \%$ of total plant carbon will return to rhizosphere, and the remaining carbon will appear as root residue with the same proportion. Carbon which returned to the soil will be around $20-40 \%$ of the total photosynthetic produced during plant growth period.

Open land with thick deposit of eruption materials, did not relatively have significant amount of pioneer vegetation. The increasing of aboveground biomass (up to $150 \mathrm{~kg} \mathrm{ha}^{-1}$ ) was correlated with the decreasing of lahar deposit, and with increasing density of pioneer vegetation. The largest biomass occurred in high vegetation density plot, followed by moderate density and low density plots (Figure 1A). This was inconsistent with Zuo et al. (2009) which showed low abundance of vegetation cover and low biomass in sand desert land. Content of soil total-C in bare land affected by Merapi eruption was only $0.1 \%$ and categorized as extremely very low. While in sparse vegetation plot, the content of total$\mathrm{C}$ increased to $0.6 \%$ and categorized as very low. Total-C increased sharply to $1.6 \%$ in moderately dense and dense vegetation plot (Figure 1B). This result showed that the existence of pioneer vegetation which grew naturally in degraded land that affected by deposit of eruption material, was able to accelerate the carbon cycle and enhance content of soil organic matter drastically, which afterwards would affect the improvement of soil physical, chemical, and biological properties. This data was consistent with Agus et 


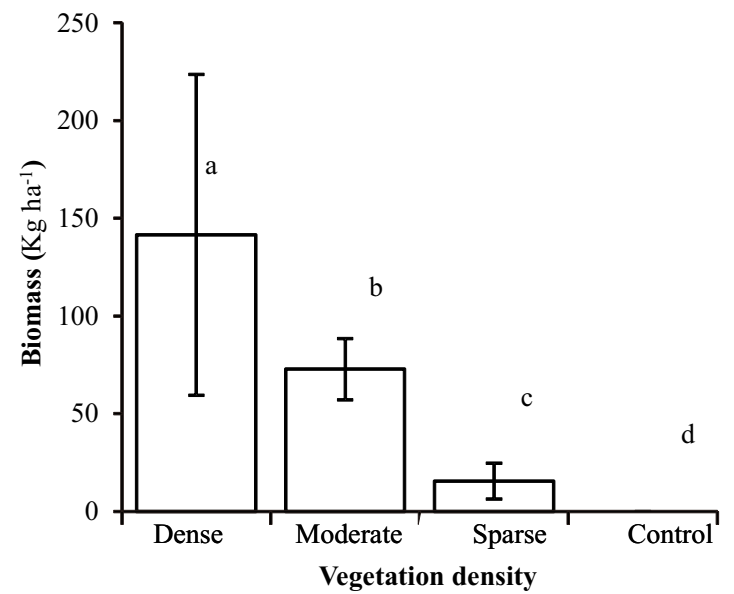

A

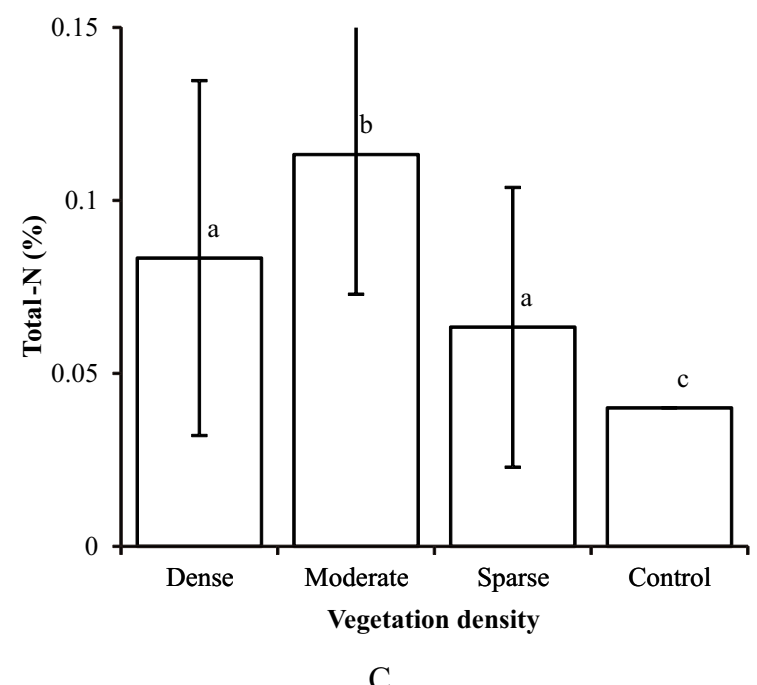

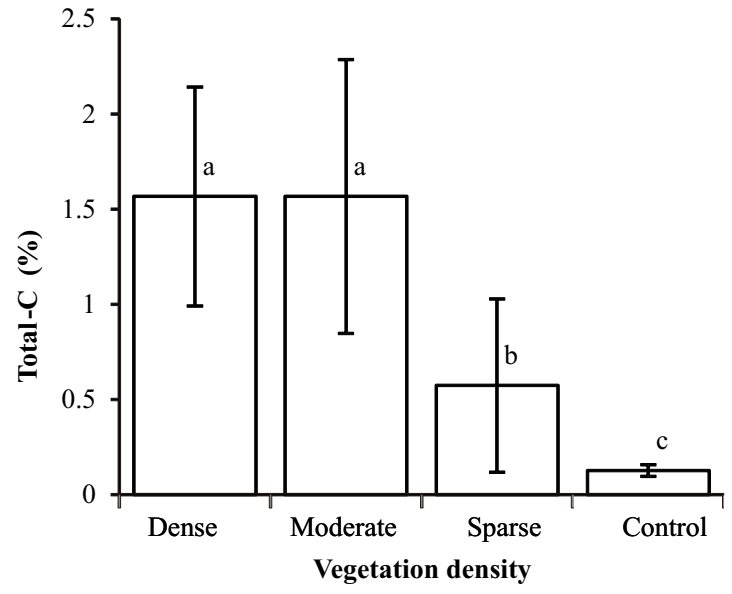

B

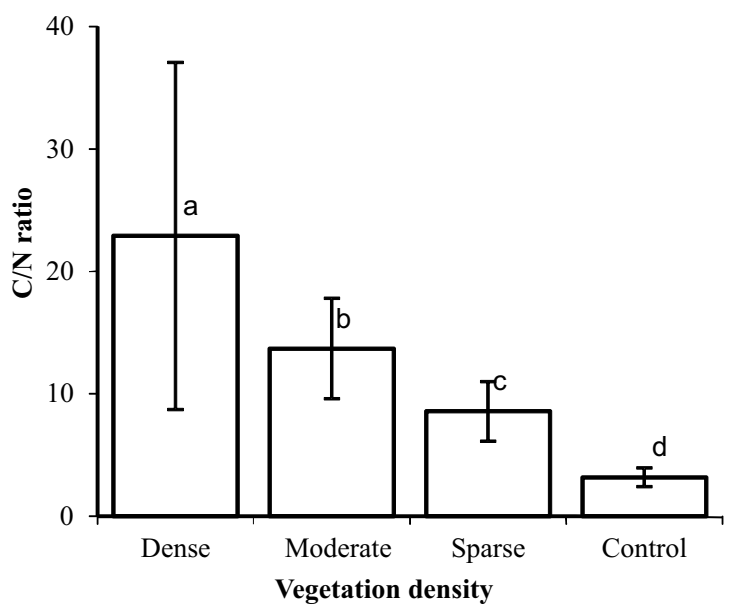

$\mathrm{D}$

Figure 1 Contents of total-C, total-N, and C-N ratio of soil at various densities of pioneer plants, 1 year after Merapi volcano eruption.

al. (2004) that showed agricultural productivity in tropical area was supported more by closed nutrient cycle, rather than by nutrient availability in the soil.

Content of soil total-N in control land without pioneer vegetation was low which was only about $0.04 \%$, and increased to $0.06 \%$ in sparse vegetation land, and increased to $0.11 \%$ in moderately dense vegetation. This content of soil total-N decreased to $0.08 \%$ in dense vegetation plot (Figure 1C). Zuo et al. (2009) also reported that N content in desert area was positively correlated with quantity of vegetation or biomass which grew upon it. The low content of soil $\mathrm{N}$ in area with dense vegetation may be due to high absorption of $\mathrm{N}$ by plants, or by $\mathrm{N}$ utilization by microorganism (Harkel et al. 1998).

Ratio of C-N in degraded land which was affected by initial eruption was only $3.2 \%$, and this increased to $8.6 \%$ in sparse vegetation plot, $13.7 \%$ in moderately dense vegetation plot, and $22.9 \%$ in dense vegetation plot (Figure 1D). Moderately dense vegetation turned out to be the best for increasing content of total- $\mathrm{C}$, total- $\mathrm{N}$, and for obtaining optimum value of $\mathrm{C}-\mathrm{N}$ as compared to bare land, sparse vegetation plot and even as compared to dense vegetation plot. Litter and natural succession of pioneer vegetation are able to supply organic matter and main nutrients for plant growth. However, in high vegetation density, there will be underground competition for nutrient absorption (Casper \& Jackson 1997). Acacia villosa possessed tendency to have lower average value of $\mathrm{C}-\mathrm{N}$ as compared to other vegetation. This was possible because this plant is member of Leguminosae family which has ability to perform symbioses with $\mathrm{N}$ fixing and $\mathrm{P}$ supplying microorganism, as proven by the finding of root nodules which occurred only in roots of this plant, and population of endomycorrhiza in its rhizosphere. This result showed that Acacia villosa possessed good 


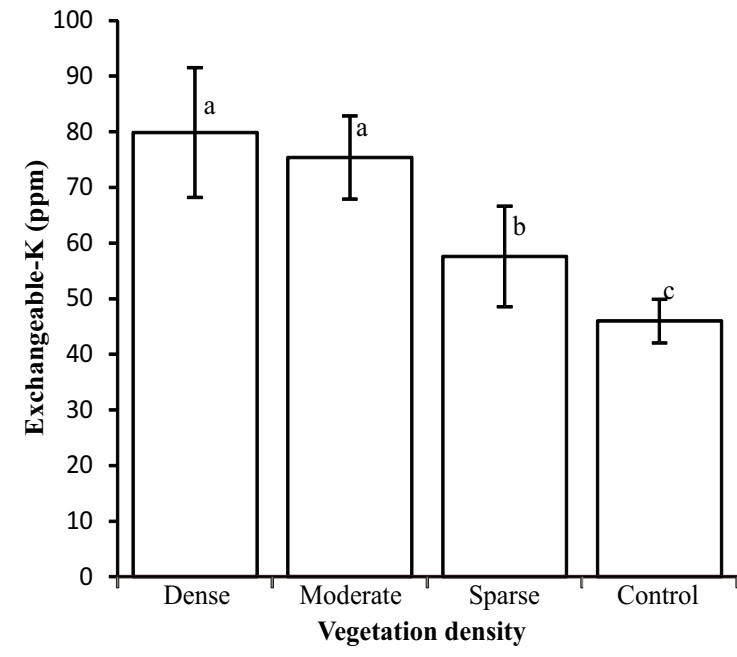

A

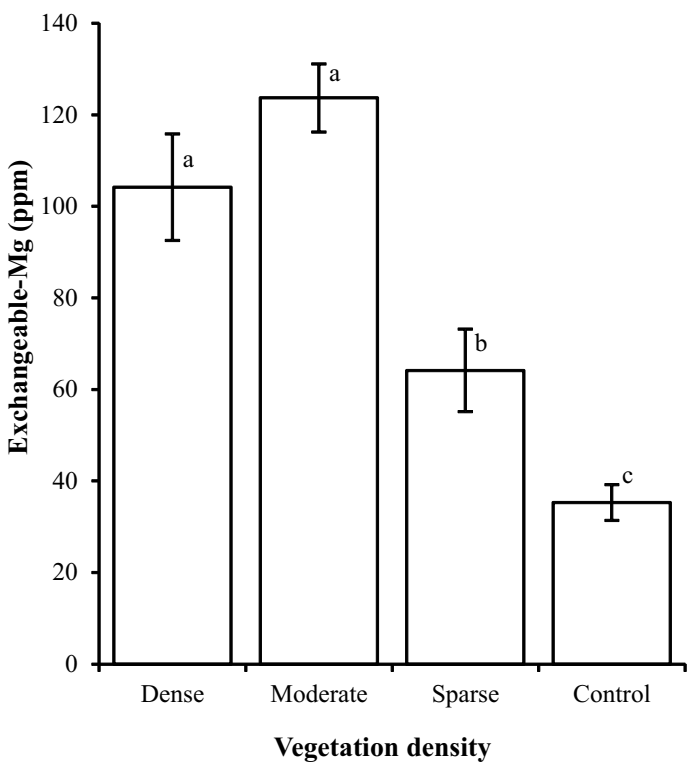

$\mathrm{C}$

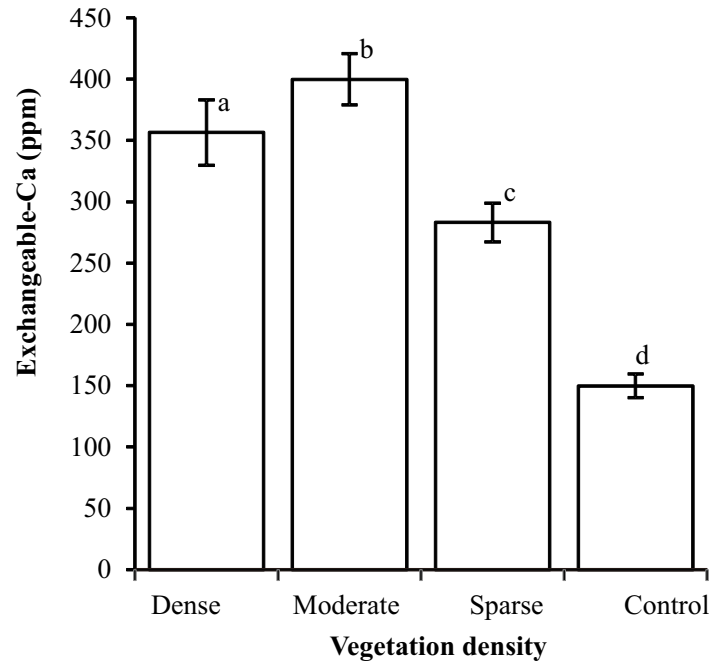

B

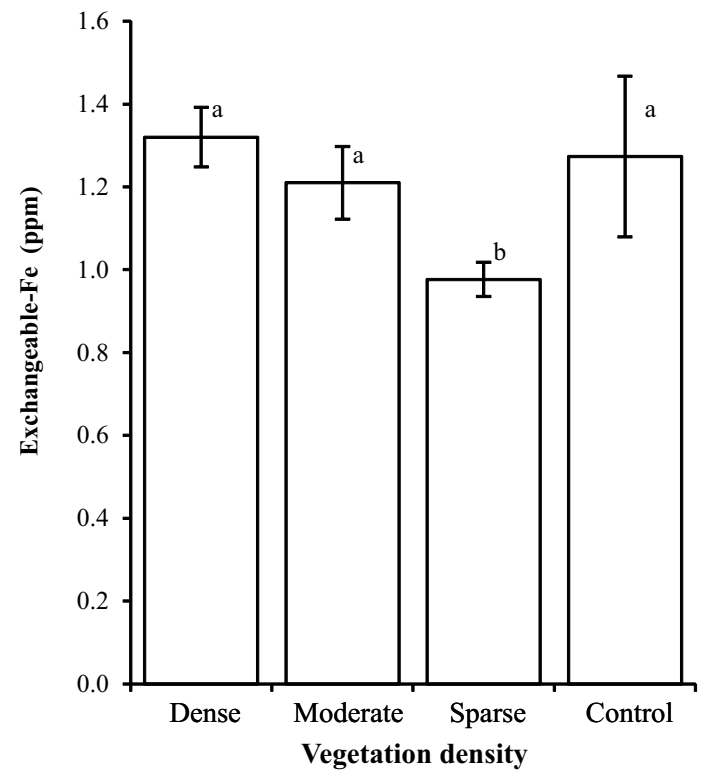

D

Figure 2 Contents of soil exchangeable-K, Ca, Mg, and Fe at various densities of pioneer plants, 1 year after Merapi volcano eruption.

potential as supplier of soil organic matter due to its possession of large biomass and moderate value of $\mathrm{C}-\mathrm{N}$ ratio. Chaer et al. (2010) reported in their research that the use of nitrogen fixing legume was able to supply organic matter and improve ecosystem biodiversity, therefore it has potential for restoring degraded land. The same result was also reported by Agus et al. (2004), which explained that legume could stimulate the increase of tropical sustainable management land productivity through $\mathrm{N}$ supply derived from $\mathrm{N}_{2}$ fixation and their organic matter.

Contents of soil exchangeable- $\mathrm{Mg}, \mathrm{Ca}$, and $\mathrm{K}$ in plots with pioneer vegetation were 2-3 times higher compared to bare land (without vegetation) of Merapi volcano eruption deposit (Figure 2). Contents of exchangeable-K in bare land was 46 ppm, whereas that of exchangeable-Ca was 150 ppm, exchangeable-Mg 35 ppm, and exchangeable-Fe 1.27 ppm, which were all categorized as very low. Content of exchangeable- $\mathrm{K}$ increased significantly in sparse pioneer vegetation to $58 \mathrm{ppm}$, whereas those in moderately dense and dense vegetation ranged between 75-80 ppm, that categorized as low content (Figure 2A). Figure 2B showed that sparse vegetation plot had greater content of exchangeable-Ca to $283 \mathrm{ppm}$, and that of moderately dense vegetation plot had exchangeable-Ca up to nearly $400 \mathrm{ppm}$. Content of exchangeable-Mg in sparse vegetation plot increased to $64 \mathrm{ppm}$ (Figure 2C), and increased nearly twice in moderately dense vegetation (124 ppm) and dense vegetation plots (104 ppm). Titus (2009) also found that content of exchangeable base nutrient increased in line with increasing of vegetation cover in slope of Mount Helens. Content of exchangeable-Fe decreased in sparse vegetation plot, but there were no significant different at moderately dense and dense vegetation plots (Figure 2D). All of these Fe contents were categorized as very low. These results 
indicated that the existence of pioneer plants potentially improve soil chemical properties as an crucial element to stimulate plant growth.

Improvement of soil physical, chemical, and biological properties will stimulate important plant succession, and the succession could be accelerated for more productive cultivation. Acceleration of organic matter cycle will greatly increase the land productivity, improvement of environment quality and plant growth. Furthermore, Agus et al. (2011) explained that Integrated Bio-cycle Farming System (IBFS) was very good in integrating all potencies of land and biological resources through 7R techniques (reuse, reduce, recycle, refill, replace, repair, and replant) so that will create an added value in economy, environment, and socio-culture sectors.

Average abundance of endomycorrhiza population exhibited large variation and showed that plants Acacia villosa (V1), Fuirena ciliaris (V2), and Bidens pilosa (V3) in each observation plot tended to have larger spore abundance

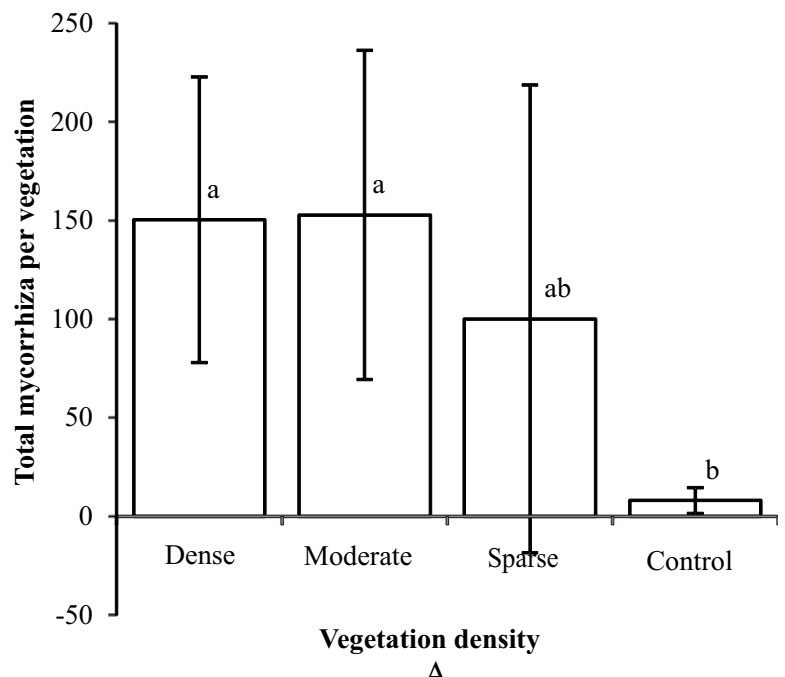

A

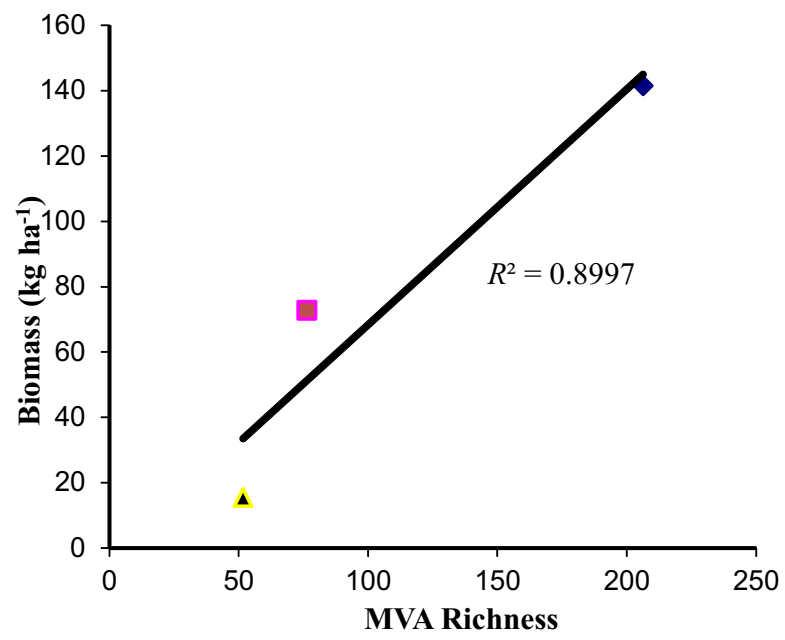

C as compared to other plants. However, this results were not in line with other researchers who showed that Fuirena ciliaris was non mycorrhiza plants (RECMS 2011) and Bidens pilosa was independent toward mycorrhiza (Perez \& Urcelay 2009), and Acacia sp. was dependent toward mycorrhiza (Jeyanny et al. 2011). The occurrence of endomycorrhiza in bare land (control), as in Figure 3A, might be due to the spore dispersion. Bagyaraj (1991) reported that dispersal of endomycorrhiza spore could occur passively through air or water, and actively through macro or microorganism which moved from one place to another. The accumulated spores will stay in dormant condition until the spores find host plants for sporulation, because their symbioses was obligate (Bagyaraj 1991). This phenomenon could be seen in observation plot with sparse vegetation plot at a thick lahar deposit land, that the mycorrhiza population was greater than those of plots without vegetation. It showed that endomycorrhiza could performed sporulation when obtaining appropriate host (Martinez-Garcia \& Pugnaire

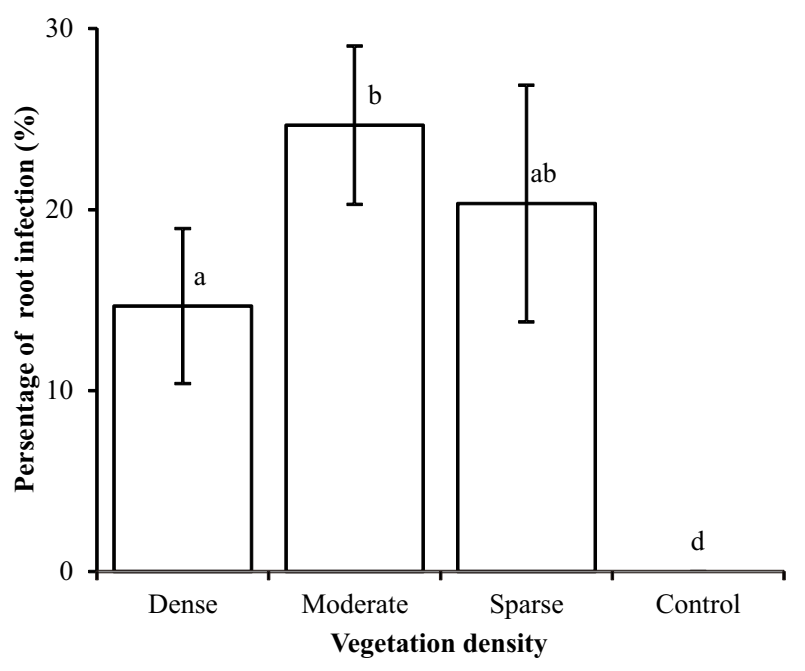

$\mathrm{B}$

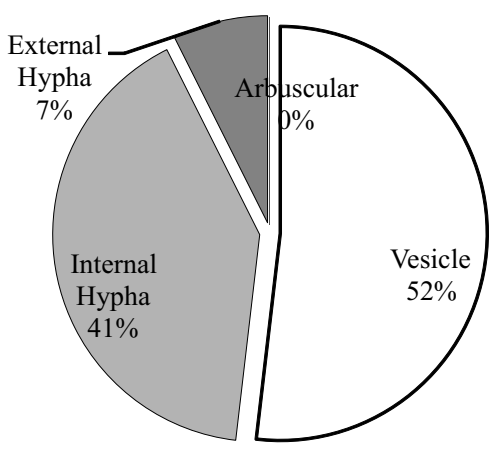

$\mathrm{D}$

Figure 3 Abundance of mycorrhiza, percentage of root infection, relation with biomass, and percentage of mycorrhiza genera at various densities of pioneer vegetation, 1 year after Merapi volcano eruption. 
2011). This phenomenon could be proven by the endomycorrhiza infection in pioneer plant roots in observation plot with sparse vegetation.

Figure 3B showed the percentage of infection intensity in each plant. Endomycorrhiza infection was characterized by the presence of vesicle, arbuscule, and internal hyphae, indicating dominance by vesicle. Arbuscule was not found because the arbuscule was a short lived organism and was soon digested by the host cell (Sieverding 1991). The infection value in this research was categorized as low, with maximum about $25 \%$. This phenomenon was happened because of infection rate was affected by many factors, such as $\mathrm{pH}$, nutrient availability, and temperature. Very low infection rate occurred in plants which suffered $\mathrm{N}$ deficiency, and this rate will increase with increasing supply of nitrogen to roots (Marschner 1995). The low content of soil total-N in this research was probably one of the reasons for low infection intensity of endomycorrhiza. Sparse vegetation plot had greater infection value than that of dense vegetation plot, although abundance of endomycorrhiza spore was not significantly different between these 2 observation plots. This phenomenon was also found by Douds and Schenck (1990) who reported that low sporulation possessed high infection rate. It was explained that carbon flow from arbucule for producing more spore, will minimize colonization or infection by mycorrhiza. Martinez-Garcia \& Pugnaire (2011) also reported that plants which could create mycorrhiza association, do not always form spores. Spore formation did not depend on high percentage of infection or infection intensity. There was no clear relationship between infection intensity and the quantity of spore production (Sparling \& Tinker 1978). Furthermore, light intensity was influenced on colonization rate of arbuscular mycorrhizal fungi (AMF) in semi tolerant wildlings (Muin et al. 2006). The amount of biomass had closed correlation with soil physical, biological and chemical properties, as well as environmental factors. There was obtained positive correlation between endomycorrhiza abundance and

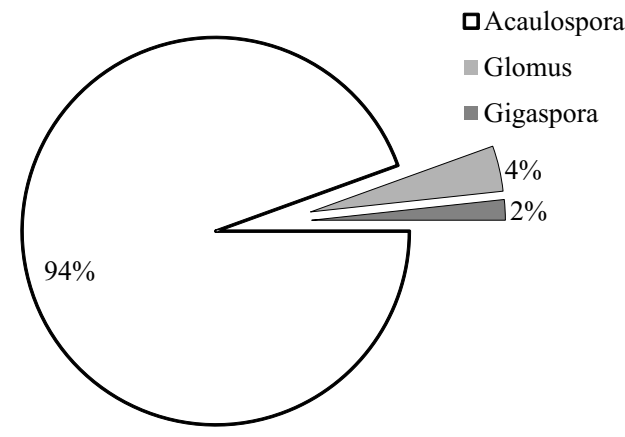

A vegetation biomass (Figure 3C). Many researches showed that mycorrhiza inoculation could assist plant growth, and finally increase their biomass production by plants, mainly in degraded lands (Alguacil et al. 2004, Zhang et al. 2011). Ability of mycorrhiza to survive at extreme condition and to associate with plants gives benefit for plant growth, particularly in the supply of essential elements, both of macro and micro elements for plants to survive in extreme condition and produce more biomass as organic matter supply (Quilambo 2003). The low content of exchangeable cations (Fe, $\mathrm{Ca}, \mathrm{K}$, and $\mathrm{Mg}$ ) and the low soil $\mathrm{pH}$ (Figure 2 and Table 1) resulted on negative impact on the environment for plant growth. However, this condition was good for mycorrhiza sporulation (Bagyaraj 1991). Therefore, the presence of mycorrhiza may solve such problems. Mycorrhiza has ability to assist plant growth and its development that finally accelerate the plant on organic matter production. Mycorrhiza fungi lived symbiotically in host plant tissue, and the fungi obtained $\mathrm{C}$ element from host plants and then returned it through the supply of essential nutrients, particularly P for the host plants (Douds \& Schenck 1990).

Based on microscopic identification, there were 3 genera of endomycorrhiza found in each rhizosphere of plants, namely Acaulospora, Glomus, and Gigaspora. Abundance of endomycorrhiza in control land was only 3 spores for each plant, whereas in sparse vegetation, this number increased sharply to 28 spores per plants. In moderately dense and dense vegetation plots, the abundance of mycorrhiza was twice higher than in sparse vegetation about 49-52 spores per plant. The presence of vegetation may serve as host for endomycorrhiza to perform sporulation. Acaulospora had the highest abundance (89-97\%) as compared to other genera in all plant rhizosphere in each observation plot (Figure 4A). Domination of Acaulospora in endomycorrhiza community was also reported by other researchers (Sarwade et al. 2011; Sturmer \& Siqueira 2011). This was possibly due to good adaptability of this spore

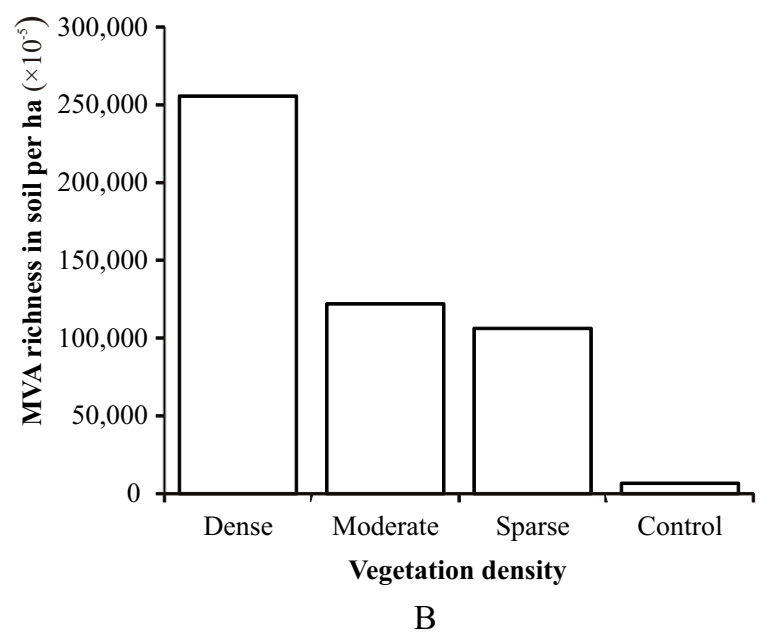

Figure 4 Percentage of endomycorrhiza abundance in roots and amount of endomycorrhiza in topsoil layer at various densities of pioneer vegetation, 1 year after Merapi volcano eruption. 
toward local environment, such as soil $\mathrm{pH}$ or soil fertility level (Sturmer \& Siqueira 2011) or also due to existence of partial control of spore distribution by rainfall, particularly in tropical region (Lovelock et al. 2003). Brundrett et al. (1996) found high abundance of Acaulospora in soil sample in different natural habitats: in degraded land and in rocky areas, and Acaulospora was found least in tropical rain forest. This result showed that Acaulospora possessed suitable natural habitat in dry areas with low level of soil fertility. Therefore, Acaulospora is a potential biological agents for rehabilitation, either in sandy lands, lands with poor fertility or in arid land.

\section{Conclusion}

Twelve species of pioneer plants were found in degraded sandy land that caused by deposit of Merapi volcanic materials. However, only Acacia villosa, Fiurena ciliaris (elephant grass), and Bidens pilosa (ketut) species which were recommended as plant-remediator because they are the most adaptive, dominant and appropriate host for mycorrhiza. Three genus of endomycorrhiza were found in degraded sandy land, but only Acaulospora species which could be recommended as bioremediator for sandy land due to its character which was most adaptive and dominant. Existence of pioneer vegetation and mycorrhiza could stimulate land quality recovery by improving soil physical, biological and chemical properties which will afterwards increase plant growth and biodiversity.

\section{Acknowledgements}

The authors express their greatest gratitude toward Faculty of Forestry, UGM, Yogyakarta which funded this research through its research funding.

\section{References}

Aggangan NS, Dell B, Malajczuk N. 1998. Effects of chromium and nickel on growth of the ectomycorrizal fungus Pisolithus and formation of ectomycorrizas on Eucalyptus urophylla S.T. Blake. Geoderma 84: 10-30. http://dx.doi.org/10.1016/S0016-7061(97)00118$\underline{3 .}$

Agus C et al. 2004. Sustainable site productivity and nutrient management in a short rotation Gmelina arborea plantation in East Kalimantan, Indonesia. New Forest Journal 28:277-285. http://dx.doi.org/10.1023 /B:NEFO.0000040954.27630.2f.

Agus C et al. 2011. Integrated Bio-cycles Farming Ssystem for production of Bio-gas through GAMA DIGESTER, GAMA PURIFICATION AND GAMA COMPRESSING. Journal of Japan Institute of Energy 90(11):1086-1090. http://dx.doi.org/10.3775/ jie.90.1085.

Alguacil MDM, Caravaza F, Diaz G, Marin P, Roldan A. 2004. Establishment of Retama sphaerocarpa L. seedlings on a degraded semiarid soil as influenced by mycorrhizal inoculation and sewage sludge amendment. Journal Plant Nutrient Soil Science 167:637-644. http://dx.doi.org/10.1002/jpln.200421422.

Austin SA. 1984. Rapid erosion at Mount St. Helens. Origins 11(2):90-98.

Bagyaraj DJ. 1991. Ecology of Vesicular Arbuscular Mycorrhizae. Bangalore: University of Agricultural Science.

Brundrett M, Bougher N, Dell B, Groe T, Malajczuk N. 1996. Working with Mycorrhizas in Forestry and Agriculture. Canberra: Australian Centre for International Agricultural Research.

Casper BB, Jackson RB, 1997. Plant competition underground. Annual Review of Ecology and Systematics 28: 545-70. http://dx.doi.org/10.1146/ annurev.ecolsys.28.1.545.

Chaer GM et al. 2010. Nitrogen-fixing legume tree species for the reclamation of severely degraded lands in Brazil. Tree Physiology 31: 139-149. http://dx.doi.org/10. 1093/treephys/tpq116.

Connel JH, Slatyer RO. 1977. Mechanism of succession in natural communities and their role in community stability and organization. The American Naturalist 111(982):1119-1144. http://dx.doi.org/10. $1086 / 283241$.

Corlett RT. 1991. Plant succession on degraded land in Singapore. Journal of Tropical Forest Science $4(2): 151-161$.

Douds DD, Schenck NC. 1990. Relationship of colonization and sporulation by VA mycorrhizal fungi to plant nutrient and carbohydrate contents. New Phytologist 116:621-627. http://dx.doi.org/10.1111/j.14698137 .1990.tb00547.x.

Garg N, Chandel S. 2010. Arbuscular mycorrhizal networks: process and functions, A review. Agronomy for Sustainable Development 30:581-599. http://dx.doi.org/10.1051/agro/2009054.

Harkel MJ, van Boxel JH, Verstraten JM. 1998. Water and solute fluxes in dry coastal dune grasslands: the effect of grazing and increased nitrogen deposition. Plant and Soil 202:1-13. http://dx.doi.org/10.1023/A:100433 6520844.

Henry M, Stevens H, Carson WP. 1999. Plant density determines species richness along an experimental fertility gradient. Ecology 80(2):455-465. http://dx.doi.org/10.2307/176625.

Jeyanny V, Lee SS, Rasidah KW. 2011. Effect of arbuscular mycorrhizal inoculation and fertilization on the growth 
of Acacia mangium seedlings. Journal of Tropical Forest Science 23:404-409.

Lei D, Duan C. 2008. Restoration potential of pioneer plants growing on lead-zinc mine tailings in Lanping, Southwest China. Journal of Environmental Science 20:1202-1209. http://dx.doi.org/10.1016/S1001-07 42(08)62210-X.

Li LJ et al. 2011. Foliar N/P ratio and nutrient limitation to vegetation growth on Keerqin sandy grassland of Northeast China. Grass and Forage Science 66:237-242. http://dx.doi.org/10.1111/j.1365-2494. 2011.00781.x.

Lovelock CE, Andersen K, Morton JB. 2003. Arbuscular mycorrhizal communities in tropical forest are affected by host tree species and environment. Oecologia $135: 268-279$.

Maki T, Nomachi M, Yoshida S, Ezawa T. 2008. Plant symbiotic microorganisms in acid sulfate soil: significance in the growth of pioneer plants. Plan Soil 310:55-65. http://dx.doi.org/10.1007/s11104-0089628-y.

Marschner H. 1995. Mineral Nutrition of Higher Plants 2nd Ed. Netherland: Academic Press. http://dx.doi. org/10.1016/B978-012473542-2/50012-2.

Martinez-Garcia LB, Pugnaire FI. 2011. Arbuscular mycorrhizal fungi host preference and site effects on two plant species in semiarid environment. Applied Soil Ecology 48:313-317. http://dx.doi.org/10.1016 /j.apsoil.2011.04.003

Muin A et al. 2006. Study on Arbuscular Mycorrhizal Fungi and Light Intensity to the Natural Regeneration of Ramin (Gonystylus bancanus (Miq.) Kurz. Journal of Tropical Forest Management 12(3):72-80.

Newhall CG et al. 2000. 10,000 years of explosive eruption of merapi volcano, Central Java: archaeological and modern implications. Journal of Volcanology and Geothermal Research 100:9-50. http://dx.doi.org/ 10.1016/S0377-0273(00)00132-3.

Norambuena VP, Luzio LW, Zepeda O, Stern J, Reinoso F. 2011. Preliminary survey of some soils from Chilean altiplano near Iquique. Journal of Soil Science and Plant Nutrition 11:62-71. http://dx.doi.org/10.4067/ S0718-95162011000200006.

Perez M, Urcelay C. 2009. Differential growth response to arbuscular mycorrhizal fungi and plant density in two wild plants belonging to contrasting functional types. Mycorrhiza 19:517-523. http://dx.doi.org/10. 1007/s00572-009-0254-1.

Prawirowardoyo S. 1987. Prosedur Analisis Kimia Tanah.
Terbitan IV. Jakarta: Departemen Pertanian.

Quilambo OA. 2003. The vesicular-arbuscular mycorrhizal symbiosis. African Journal of Biotechnology (12):539-546.

[RECMS] Roadside Erosion Control and Management Study. 2011. Mycorrhiza: issues relative to roadside tevegetation. Earth and Soil Science Department. Cal Poly State University. San Luis Obispo, CA 93407-0261. . [7 Maret 2012].

Sarwade PP, Chandanshive SS, Kanade MB, Bhale UN. 2011. Diversity of arbuscular mycorrhizal (AM) fungi in some common plants pf marathwada region. International Multidisiplinary Research Journal $1(12): 11-12$

Schenck NC. 1982. Methods and Principles of Mycorrhizal Research. Minnesota: The American Phytopathological Society.

Sieverding E. 1991. Vesicular Arbuscular Mycorrhiza Management in Tropical Agrosystem. Federal Republic of Germany: GTZ GmbH.

Sklenar P, Kovar P, Palice Z, Stancik D, Soldan Z. 2010. Primay succession of high altitude andean vegetation on lahars of Volcan Cotopaxi, Ecuador. Phytocoenologia 40:15-28.

Soerjani M, Kostermans AJGH, Tjitrosoepomo G. 1987. Weeds of Rice in Indonesia. Jakarta: Balai Pustaka.

Solaiman MZ, Hirata H. 1997a. Effect of indigenous arbuscular mycorrhizal fungi in paddy fields on rice growth and NPK nutrition under different water regimes. Soil Science and Plant Nutrition 41:505-514. http://dx.doi.org/10.1080/00380768.1995.104196 $\underline{12}$

Solaiman MZ. Hirata H. 1997b. Effect of arbuscular mycorrhizal fungi inoculation of rice seedlings at the nursery stage upon performance in the paddy field and greenhouse. Plant and Soil 191:1-12. http://dx.doi. org/10.1023/A:1004238028617.

Sparling BP, Tinker PB. 1978. Mycorrhizal infection in pennine grassland. II. Effects of mycorrhizal infection on the growth of some upland grass on gamma-irradiated soils. Journal of Applied Ecology 15:951-958. http://dx.doi.org/10.2307/2402790.

Sturmer SL. Siqueira JO. 2011. Species richness and spore abundance of arbuscular mycorrhizal fungi across distinct land uses in western Brazialian Amazon. Mycorrhiza 21:255-267. http://dx.doi.org/10.1007/ s00572-010-0330-6.

Titus JH. 2009. Nitrogen-fixers Alnus and Lupinus influence soil characteristics but not colonization by 
later successional species in primary succession on Mount St. Helens. Plant Ecology 203:289-301. http://dx.doi.org/10.1007/s11258-008-9549-0.

Vaje PI, Singh BR, Lal R. 2005. Soil erosion and nutrient losses from volcanic ash soil in Kilimanjaro region, Tanzania. Journal of Sustainable Agriculture 26(4):95-117.

Wilson T, Kaye G, Stewart C, Cole J. 2007. Impacts of the 2006 eruption of merapi volcano, Indonesia, on agriculture and infrastructure. GNS Science Report. Institute of Geological and Nuclear Science Limited, 2007. [5 Maret 2012].

Zhang X, Zhang Y, Chao H. 2004. Pioneer plants for ecosystem recovery in drainage basin of erlongshan reservoir in Heilongjiang Province, China. Chinese Geographical Science 14(4):377-381. http://dx. doi.org/10.1007/s11769-004-0044-9.

Zhang YF et.al. 2011. Arbuscular mycorrhizal fungi improvere establishment of Leymus chinensis in bare saline-alkaline soil: Implication on vegetation restoration of extremely degraded land. Journal of Arid Environment 75:773-778. http://dx.doi.org/ 10.1016/j.jaridenv.2011.04.008.

Zuo X et al. 2009. Vegetation pattern variation, soil degradation and thei relationship along a grassland desertification gradient in Horqin sandy land, northern China. Environmental Geology 58:1227-1237. http://dx.doi.org/10.1007/s00254-008-1617-1. 